\title{
Trykk og tråkk
}

Kalosjer er på moten igjen, men kalosjefabrikker finnes det ikke mer her i landet. I Tidsskriftet nr. 12/1937 presenteres en fotbetjent pumpeanordning for blodtrykksapparater, uteksperimentert i samarbeid med Den norske kalosje- og gummivarefabrikk. Den skulle gjøre blodtrykksmålingen mindre tidkrevende og gi legen hendene fri (Tidsskr Nor Lægeforen 1937; 57: 669-70).

\section{En praktisk anordning til blodtrykksapparat ved masseundersøkelser.}

Av Birger Hannisdahl, Oslo.

Det forlanges i almindelighet ved en blodtrykksmåling i våre dager at det systoliske blodtrykk skal angis så vel palpatorisk som auskulatorisk. Likeledes skal det diastoliske trykk angis auskulatorisk. For å kunne utføre en sådan måling - så vel ved palpitasjon som auskultasjon - er det ønskelig å ha begge hender fri. Man må ellers ved de vanlige apparater pumpe op en gang for palpatorisk og en gang til for auskulatorisk måling. Â pumpe op to ganger er tidrøvende, likesom en del patienter synes det er ubehagelig å sitte med armen avklemt så lenge. For å gjøre denne tidrøvende process noget mere lettvint blev der laget en gummiballong som betjenes med foten. Herved blir begge hender fri - det kan samtidig : ved en opblåsning og trykksenking - måles så vel palpatorisk som auskulatorisk. Denne måleanordning har også den store fordel at det lettvint - ved trykkregulering med foten - kan kontrollmåles flere ganger. Gummiballongen har nemlig så stort volum at man ved å variere trykket med foten kan senke trykket nedenfor det diastoliske og heve det over det systoliske - bare ved å trå hårdere og lettere på ballongen. Hele anordningen er en gummiballong med ventil og en vel meterlang slange som forener ballongen med manometeret. Gummiballongen anbringes på gulvet.

Da forfatteren ikke har kunnet finne lignende anordning beskrevet noget sted, tillater jeg mig å omtale denne lille anordning som ved to års prøvning ved Idrettslægekontoret har vist sig å være praktisk. Hvor det måles en del blodtrykk i privatpraksis på kontoret, torde også en sådan anordning være hensiktsmessig.

Jeg vil få rette en takk til ledelsen ved Den norske kalosje- og gummivarefabrikk, Mjøndalen, særlig ingeniør Hassel for all velvilje ved uteksperimenteringen.

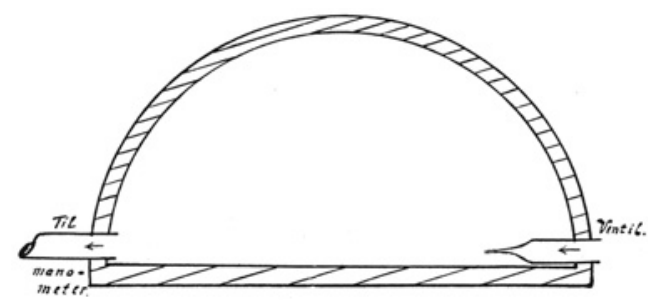

Skjematisk snitt gjennem gummiballong til betjening med foten.

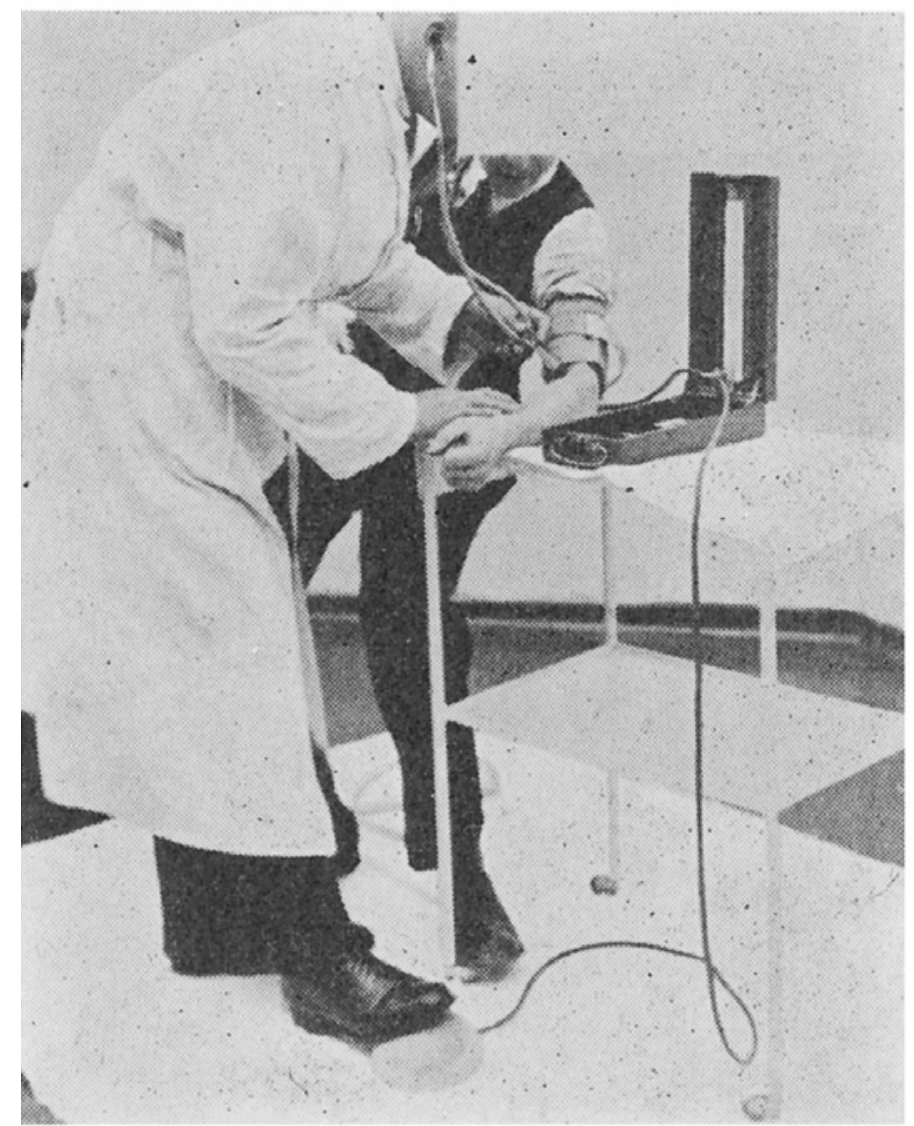

Ved et par raske pumpetak med foten opnåes et lett trykk på ca. 50 mm. i systemet, til tross for at det kun er enveisventil i ballongen. Den sterke ekspansjonskraft i ballongen fremkaller nemlig sterk luftfortynning her når foten løftes under pumpetakene. Lufttilstrømningen til gummiballongen skjer da lettere gjennem ventilen enn gjennem gummislangen hvor motstanden er større. Denne tilbakestrømning gjennem gummislangen kan lett reguleres ved en klemskrue som innstilles en gang for alltid. Dette kan bli nødvendig hvis det benyttes stordimensjonert gummislage. Ved dimensjon ca. $1 / 2 \mathrm{~cm}$. er dette ikke nødvendig. 